\title{
Nacre morphology and chemical composition in Atlantic winged oyster Pteria colymbus (Röding, 1798)
}

\author{
Pablo Santana ${ }^{1}$, Dalila Aldana Aranda ${ }^{\text {Corresp. } 1}$ \\ ${ }^{1}$ Departamento de Recursos del Mar, Centro de Investigación y de Estudios Avanzados del Instituto Politécnico Nacional, MERIDA, Yucatán, México \\ Corresponding Author: Dalila Aldana Aranda \\ Email address: daldana@cinvestav.mx
}

The microstructure and nanostructure of nacre in Pteria colymbus were studied with highresolution field emission scanning electron microscopy (FESEM). The tablets were found to be flat and polyhedral with four to eight sides, and lengths ranging from 0.6 to $3.0 \mu \mathrm{m}$. They consisted of nanocrystals $41 \mathrm{~nm}$ wide, growing in the same direction. X-ray diffraction showed the crystals to be mineral phase aragonite, which was confirmed by Raman spectroscopy. Fourier transform infrared spectroscopy identified a band at 1786.95 $\mathrm{cm}^{-1}$ attributed to carboxylate (carbonyl) groups of the proteins present in the organic matrix as well as bands characteristic of calcium carbonate. X-ray fluorescence showed the nacre to contain $98 \%$ calcium carbonate, as well as minor elements ( $\mathrm{Si}, \mathrm{Na}, \mathrm{S}$ and $\mathrm{Sr}$ ) and trace elements ( $\mathrm{Mg}, \mathrm{P}, \mathrm{Cu}, \mathrm{Al}, \mathrm{Fe}, \mathrm{Cl}, \mathrm{K}$ and $\mathrm{Zn}$ ). 


\section{Nacre morphology and chemical composition in}

2 Atlantic winged oyster Pteria colymbus (Röding, 1798)

3

4

5

6

7

8

9

10

11

12

13

14

15

16

17

18

19

20

21

22

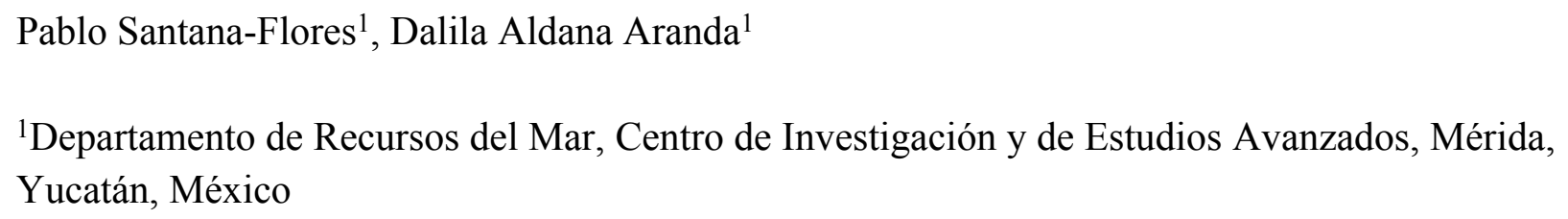

\section{Abstract}

The microstructure and nanostructure of nacre in Pteria colymbus were studied with high resolution field emission scanning electron microscopy (FESEM). The tablets were found to be flat and polyhedral with four to eight sides, and lengths ranging from 0.6 to $3.0 \mu \mathrm{m}$. They consisted of nanocrystals $41 \mathrm{~nm}$ wide, growing in the same direction. X-ray diffraction showed the crystals to be mineral phase aragonite, which was confirmed by Raman spectroscopy. Fourier transform infrared spectroscopy identified a band at $1786.95 \mathrm{~cm}^{-1}$ attributed to carboxylate (carbonyl) groups of the proteins present in the organic matrix as well as bands characteristic of calcium carbonate. X-ray fluorescence showed the nacre to contain $98 \%$ calcium carbonate, as well as minor elements ( $\mathrm{Si}, \mathrm{Na}, \mathrm{S}$ and $\mathrm{Sr}$ ) and trace elements ( $\mathrm{Mg}, \mathrm{P}, \mathrm{Cu}, \mathrm{Al}, \mathrm{Fe}, \mathrm{Cl}, \mathrm{K}$ and $\mathrm{Zn}$ ).

\section{Introduction}

Mollusk shells are mineralized tissues that fulfill structural functions (Addadi, Raz \& Weiner, 2003). In all three main mollusk classes (Cephalopoda, Gastropoda and Bivalvia) the shell consists of stratified layers, each with a unique mineral composition (Dauphin \& Denis, 2000). Shellforming crystals are organized on these layers according to different configurations which define a shell's microstructures. Specific microstructures are characteristic of calcite (i.e., prismatic, foliate) and aragonite (i.e., nacre, laminar cross). Secreted polymorph type and microstructural types are used to characterize large mollusk groups, particularly the bivalves. 
34 Nacre is the most studied aragonitic microstructure and is widely distributed in mollusks (Towe \& 35 Hamilton, 1967). Its stratified microstructure gives mother-of-pearl its luster and provides

36

37

38

39

40

41

42

43

44

45

46

47

48

49

50

51

52

53

54

55

56

57

58

59

60

61

62

63

64

excellent mechanical properties. Nacre has been of great interest to the pearl industry, making it one of the most studied hard tissues (Wang et al., 2013). Because it is osteoconductive and biodegradable, interest has increased recently in technological applications related to nacre, such as the manufacture of bio-inspired super-resistant materials and clinical implants (Tang et al., 2003; Oaki \& Imai, 2005).

In each of the three main mollusk classes (Gastropoda, Cephalopoda and Bivalvia) nacre exhibits specific growth patterns and mechanisms. In Gastropoda, for example, the aragonite nanocrystals in the nacre are stacked in towers and their c axes are aligned. However, they have a composite cross laminar arrangement, and a third hierarchical order of flat aragonite fibers from 50 to 100 $\mathrm{nm}$ thick, $300 \mathrm{~nm}$ wide and a few micrometers long (Romana et al., 2013). In the nautilus (Cephalopoda), nacre exhibits a mixed behavior with simultaneous growth in towers and terraces occurring in adjacent locations (Saunders \& Landman, 2010). Nacre in the Bivalvia has terraced growth and the three axes of crystals are co-oriented. The order Pterioidae has shells that are unequal, monomyary, and not equilateral; the right valve is generally less convex than the left (Wada \& Tëmkin, 2008; Cummings \& Graf, 2015). Their shells are formed by superposition of an outer organic layer, the periostracum, a prismatic layer and the inner nacreous layer (Kennedy, Taylor \& Hall, 1969).

Nacre is a biomineral consisting (by weight) of $95 \%$ aragonite $\left(\mathrm{CaCO}_{3}\right)$ with the remaining 1 to $5 \%$ being organic matrix(Zhang \& Li, 2012). Its microstructure is one of layered "brick" (aragonite tablets) and "mortar" (protein-polysaccharide matrix). This structure provides nacre with twice the strength and up to 1000 times the toughness of its constituent components alone (Li et al., 2004; Veis \& Dorvee, 2013; Morris et al., 2016). Individual nacre tablets have a nanoscale structure based on aragonite nanograins, nanoblocks and nanofibers (Wang et al., 2013). Nanoscale structural organization differs between bivalve mollusks, resulting in different tablet forms at growth completion.

Better understanding of the composition and hierarchy of biological system microstructures is key in the search for new materials and provides deeper insight into evolutionary processes (JáureguiZúñiga et al., 2003; Oaki \& Imai, 2005; Wang et al., 2013; Nakamura Filho et al., 2014; Wegst et al., 2015). The present study objective was to analyze the micro- and nanostructure of $P$. colymbus

Peer) reviewing PDF | (2021:01:57287:1:0:NEW 2 May 2021) 
65

66

67

68

69

70

71

72

73

74

75

76

77

78

79

80

81

82

83

84

85

86

87

88

89

90

91

92

93

94

95

nacre with scanning electron microscopy, and its chemical composition with x-ray diffraction, Xray fluorescence spectrometry, Fourier transform infrared spectrometry and Raman spectroscopy.

\section{Materials \& Methods}

Shells of Pteria colymbus were collected in the Alacranes Reef, in the state of Yucatán, Mexico. They were placed in a soap solution, cleaned, and stored at $4{ }^{\circ} \mathrm{C}$ for 48 hours. To remove the inorganic and biogenic matter from shells was cleaned by ultrasound with a soap solution for five minutes. (Ky, Lo \& Planes, 2017). Six $1 \mathrm{~cm}^{2}$ samples were cut from the shells using a $32 \mathrm{~mm}-$ diameter diamond disc. Samples were washed again by ultrasound for five minutes and dried at 65 ${ }^{\circ} \mathrm{C}$ for three hours (Ren et al., 2009; Xu \& Zhang, 2015).

Nacre tablet morphology was characterized with a JEOL 7600F ultra high resolution field emission scanning electron microscope (FESEM). Samples were coated with $\mathrm{Au} / \mathrm{Pd}$ and processed at a 1$30 \mathrm{kV}$ acceleration voltage (Ren et al., 2009; Liu \& Li, 2015).

For the chemical analysis, a $1 \mathrm{~cm}^{2}$ nacreous layer sample was separated from the shell with the help of a rotary tool at 2000 RPM. The sample was always kept immersed in water at room temperature. The sample was cleaned by ultrasound with a soap solution for five minutes and dried at $65{ }^{\circ} \mathrm{C}$ for three hours. Subsequently, it was placed in aluminum sample holders for analysis in the diffractometer (Bruker D8) using monochromatic CuKa radiation. The XRD patterns were collected at 20 to $90^{\circ}(2 \Theta)$ in $0.02^{\circ}$ steps with a $0.96 \mathrm{~s}$ count time interval. The resulting diffraction patterns were compared with the card for aragonite (PDF no. 000411475) from the crystallographic records of the International Center for Diffraction Data (ICDD) database (Weiner \& Traub, 1980; de Paula \& Silveira, 2009; Heinemann et al., 2011).

To analyze the nacre by Fourier transform infrared spectrometry (FTIR) analysis, the nacre layer from the shell was separated with a rotary tool at 2000 RPM. The sample was ultrasonically cleaned with a soap solution and dried at $65^{\circ} \mathrm{C}$ for 3 hours. The sample was ground in an agate mortar to give the appearance of a fine powder and then dried at $65^{\circ} \mathrm{C}$ for 3 hours. Tablets were prepared with $0.5 \mathrm{mg}$ of nacre powder and $200 \mathrm{mg}$ of $\mathrm{KBr}$. Infrared analyzes were run at a $4 \mathrm{~cm}$ resolution in two wave ranges: $400-4000 \mathrm{~cm}^{-1}$ and $550-4000 \mathrm{~cm}^{-1}$. The analyzes were done in reflectance mode on a FTIR spectrometer with Bruker accessory (EQUINOX 5). Spectra were automatically corrected for water, carbon dioxide and the $\mathrm{KBr}$ background (Monarumit et al., 2015; Zhang et al., 2016; Cardoso et al., 2016). 
96 Chemical analyses were also done using the semi-quantitative method of X-ray fluorescence 97 spectrometry (XFR) with wave dispersion in a spectrometer (Bruker S4 Pioneer) with a $4 \mathrm{~kW}$

excitation source. A vacuum scan was done of 71 elements (11Na-92U) using an RX tube with Rh anode, 25 to $60 \mathrm{kV}$ excitation voltage, and a $0.46 \mathrm{dg}$ collimator with a $34 \mathrm{~mm}$ mask. Data was interpreted with the Spectra Plus software. Quantification of $\mathrm{CaCO}_{3}$ was done with an ignition loss analysis at $950{ }^{\circ} \mathrm{C}$ for one hour (Shi et al., 2018).

The $\mathrm{CaCO}_{3}$ crystalline phase was identified using a Raman spectrometer with focal point (WITEC Alpha 300) $\left(\lambda \operatorname{exc}=488\right.$ and $785 \mathrm{~nm}$; acquisition time $10 \mathrm{~s}$; resolution $\left.10 \mathrm{~cm}^{-1}\right)$.

\section{Results}

Microstructure and nanostructure

The shell of $P$. colymbus consists of a prismatic and an aragonitic layer clearly divided by a slight change in color (Figure 1, indicated by arrow and BL symbol). The FESEM analysis identified an organic hydrogel on some tablets in different layers (Figure 2a). In another growth section of the pearlescent layer small growing crystals were observed to be fusing with each other (Fig. 2b). The tablets form a uniform sheet at the point where the next layer begins to grow and in some cases the tablets fuse with higher layers (Figure 2c). Mature tablets are four to eight-sided, 0.6 to $3.0 \mu \mathrm{m}$ in length, and can be fused (Figure 2d).

Cross sections of the nacre tablets showed a nanostructure in which the first layer of deposited nacre consisted of packed nanocrystals forming tablets. These were longer than in the upper layers and their growth was perpendicular to the surface (Figure 3a). Crystals in initial growth stages were observed in a section close to the prismatic layer (Figure 3b). In the intermediate section of the shell all the deposited nacre layers contained tablets composed of a package of crystals fused in the "brick and mortar" arrangement typical of species in the Pteriidae family. Average tablet thickness was $385 \mathrm{~nm}(\mathrm{SD}=0.069)(\mathrm{n}=187)$ with a range of 200 to $530 \mathrm{~nm}$ (Figure $3 \mathrm{c})$. The nanocrystals were uniformly oriented perpendicular to shell surface, have a $41 \mathrm{~nm}(\mathrm{SD}=9.43)$ (n $=24)$ average width, and a length range of 24 to $69 \mathrm{~nm}(\mathrm{n}=24)$ (Figure $3 \mathrm{~d})$.

\section{Chemical analysis}

The XRD pattern of the nacre layer showed the main reflection to be at 31.05 (2Ө) with two lesser readings at $33.0(2 \Theta)$ and $66.0(2 \Theta)$, both characteristic of aragonite (Figure 4). 
126 The XRF analysis identified aragonite as representing 98.13\% of sample weight. Minor elements 127 were $\mathrm{Si}(0.72 \%), \mathrm{Na}(0.5500 \%), \mathrm{S}(0.2080 \%)$, and $\mathrm{Sr}(0.1042 \%)$, and trace elements were $\mathrm{Mg}$ 128 (0.0897\%), P (0.0485\%), Cu (0.0353\%), Al (0.0331), Fe (0.0311\%), Cl (0.0290\%), K (0.0151\% 129 and $\mathrm{Zn}(0.0060 \%)$. The nacre's aragonite structure was confirmed in the FTIR analysis (Figure 5). 130 Four bands characteristic of aragonite, corresponding to the $\mathrm{CO}_{3}{ }^{2-}$ ions, were identified: v3 at $1311445.96 \mathrm{~cm}^{-1}$; v1 at $1082.72 \mathrm{~cm}^{-1}$; v2 at $856.80 \mathrm{~cm}^{-1}$; and $\mathrm{v} 4$ at $699.81-712.52 \mathrm{~cm}^{-1}$. The v4 band 132 corresponds to the planar flexion mode of carbonate vibration and the $\mathrm{v} 1$ band to the symmetric 133 stretch mode. The nacre FTIR spectrum revealed lower intensity organic bands; the band at $1341786.95 \mathrm{~cm}^{-1}$ was attributed to the carboxylate (carbonyl) groups of the acidic proteins in the 135 organic matrix.

136 The Raman spectroscopy analysis of the nacre surface produced the most intense band at near $1371085 \mathrm{~cm}^{-1}$ in the aragonite spectra which corresponds to symmetrical stretching mode v1 of the 138 carbonate ion (Figure 6). Low- to medium-intensity bands in the $100-300 \mathrm{~cm}^{-1}$ region of the 139 aragonite spectra were due to the translational and rotational modes of lattice vibration. The v4 in 140 the carbonate ion plane bending mode occurred as a doublet with bands between 701 and $705 \mathrm{~cm}^{-1}$. 141

\section{Discussion}

143 Nacre in P. colymbus consists of polygonal tablets with four to eight sides, a morphological 144 characteristic also present in species such as Pinctada maxima, Pinctada radiata and Pinctada 145 fucata (Wang et al., 2001; Bellaaj-Zouari et al., 2011; Zhang, Xie \& Yan, 2019). However, tablet 146 length differs between species in the Pteriidae family. In P. colymbus, length ranges from 0.6 to $1473.0 \mu \mathrm{m}$, whereas in $P$. radiata it ranges from 4.0 to $5.0 \mu \mathrm{m}$ (Bellaaj-Zouari et al., 2011), and in $P$. 148 margaritifera from 5.0 to $10.0 \mu \mathrm{m}$ (Rousseau et al., 2009).

149 Morphological differences in pearl oysters can be seasonal or intrinsic to each species (Wada, 150 1972). Intrinsic differences are due to genetic control of shell mineralogy and any similarities 151 between species can be traced to the Mesozoic/Paleozoic boundary (Kennedy, Taylor \& Hall, 152 1969). Environmental factors such as temperature can modify shell structure in different 153 organisms. For instance, shell aragonite percentage in the mussel Mytilus californianus decreases 154 from $45 \%$ in the spring to $30 \%$ in the winter, but only in organisms longer than $15 \mathrm{~mm}$ (Kennedy, 155 Taylor \& Hall, 1969). Slower nacre deposition rates may be in response to reductions in water 156 temperature, probably in winter, combined with lower food availability (Taylor \& Strack, 2008). 
157 In another example, in P. fucata nacre growth and thickness respond to tablet thickness which is $158324 \mathrm{~nm}$ when water temperature is highest, during August, but only $224 \mathrm{~nm}$ when it is lower, in 159 December (Muhammad et al., 2017). Decreases in tablet thickness favor light iridescence of the 160 nacre surface which is why pearl producers harvest pearls when sea water temperature decreases 161 (Suzuki \& Nagasawa, 2013).

162 The tablets in P. colymbus shell contain nanocrystals ranging in thickness from 24 to $69 \mathrm{~nm}$. This 163 coincides with tablets in P. maxima which consist of aragonite nanofibrils from 10 to $30 \mathrm{~nm}$ thick 164 (Wang et al. 2012). Tablets in abalone Haliotis rufescens shell are built of parallel aragonite 165 nanoparticles (Huang and Li 2012), and its nanostructure is one of polygonal cobble-like grains 166 $(\sim 32 \mathrm{~nm})$ within individual aragonite tablets (Li et al. 2004). The shell of P. fucata contains

167 168

169

170

171

172

173

174

175

176

177

178

179

180

181

182

183

184

185

186

187 nanoblocks from 20 to $180 \mathrm{~nm}$ long (Oaki \& Imai, 2005).

In each species formation of the aragonite nanoparticles in nacre tablets is regulated by organic matrix characteristics (Dauphin and Denis, 2000, Kim et al. 2006). The distribution of organic macromolecules during crystal growth is important since these regulate crystal size, shape, and orientation (Okumura et al., 2012; Shtukenberg, Ward \& Kahr, 2017).

In Tellinella asperrima shells, the crystallographic orientation of aragonite between nacre and nacre powder (ground at $45 \mu \mathrm{m}$ ) was investigated. It was found that there is a strong preferential crystallographic orientation of the diffraction peak at the angle $2 \Theta=31.03^{\circ}$ of the intact nacre, simultaneously two other peaks with weak preferential orientations were found (Ren et al. 2000). In this work, it was found that the X-ray diffraction pattern of the nacre of $P$. colymbus is very similar to the intact nacre of T. asperrima. Presenting greater intensity in the main diffraction peak and the same intensity in the minor peaks. This preferential crystal orientation of aragonite in nacre is frequently found in biological mineralization and is due to the presence of b-chitin fibrils and the protein polypeptide chains that control crystal growth. (Feng et al 2000).

Calcium carbonate $\left(\mathrm{CaCO}_{3}\right)$ in the form of aragonite represents $98.13 \%$ of the total nacre layer in $P$. colymbus in the present results. The majority presence of aragonite in the shell coincides with other species in the Pteriidae family, such as P. fucata (Saruwatari et al., 2009) and $P$. margaritifera (Shi et al., 2018), as well as the mussel Perna viridis (Xu \& Zhang, 2015). Minor elements are $\mathrm{Si}, \mathrm{Na}, \mathrm{S}$ and $\mathrm{Sr}$, and trace elements are $\mathrm{Mg}, \mathrm{P}, \mathrm{Cu}, \mathrm{Al}, \mathrm{Fe}, \mathrm{Cl}, \mathrm{K}$ and $\mathrm{Zn}$. In another study, nacre was found to be composed of calcium carbonate $(91.50 \%)$ with traces of organic substances $(3.83 \%)$, residual substances $(0.01 \%)$ and water (3.97\%) (Taylor \& Strack, 2008). 
188 These residual substances include $\mathrm{Na}, \mathrm{Cl}$ and $\mathrm{K}$, as well as traces and other elements such as $\mathrm{Ba}$, $189 \mathrm{Mg}, \mathrm{P}, \mathrm{Mn}, \mathrm{Fe}, \mathrm{Al}, \mathrm{Cu}, \mathrm{Zn}, \mathrm{Ag}, \mathrm{Hg}, \mathrm{Li}$ and $\mathrm{Mr}$. The trace element profile of a nacre reflects water 190 mineral composition in the place where it formed. In biogenic aragonite crystals other elements 191 such as Mn, Mg, Sr, and Ba can substitute for calcium (Gaetani \& Cohen, 2006; Chen et al., 2011). 192 Notable differences in the concentration of these elements exist between taxonomic groups, 193 highlighting genetic influence on their incorporation (Carré et al., 2006).

194 The other elements present in nacre function as precursor ions in nacre formation, as catalysts in 195 proteins and activators of enzymes; they are present in intercrystalline organic macromolecules 196 and the organism's epithelial fluid (Marsh \& Sass, 1983; Cho \& Jeong, 2011; Marin, 2012).

197

198

\section{Conclusions}

199

Nacre composition in P. colymbus has high aragonite content and its nanostructure consists of 200 polygonal tablets built of nanocrystals. The present is a preliminary description of $P$. colymbus 201 carapace structure intended as a presentation of the relevant data to date, and a guide for further 202 research.

203

204

205

\section{Acknowledgements}

206

207

208

209

210

211

212

213

214

215

The authors thank Patricia Quintana access to LANNBIO facilities, Dora Huerta, and Daniel Aguilar for assistance with the diffractograms and SEM images. The authors also thank Maria del Socorro Garcia Guillermo, Ixchel Rubí Perez, Ana Elena Muñiz, and Norma Alicia Berlanga, at Cinvestav-Saltillo chemical analysis General Laboratory for her support in carrying out this work.

\section{References}

Addadi L, Raz S, Weiner S. 2003. Taking advantage of disorder: amorphous calcium carbonate and its roles in biomineralization. Advanced Materials 15:959-970. DOI: 10.1002/adma.200300381.

Bellaaj-Zouari A, Chérif K, Elloumi-Hannachi I, Slimane N, Habib J. 2011. Characterization of mineral and organic phases in nacre of the invasive pearl oyster Pinctada radiata (Leach, 1814). Cahiers de Biologie Marine 52:337-348. 
216 Cardoso SSS, Cartwright JHE, Checa AG, Sainz-Díaz CI. 2016. Fluid-flow-templated self-assembly of 217 calcium carbonate tubes in the laboratory and in biomineralization: the tubules of the watering218 pot shells, Clavagelloidea. Acta Biomaterialia 43:338-347. DOI: 10.1016/j.actbio.2016.07.005.

219 Carré M, Bentaleb I, Bruguier O, Ordinola E, Barrett NT, Fontugne M. 2006. Calcification rate influence 220 on trace element concentrations in aragonitic bivalve shells: evidences and mechanisms.

221 Geochimica et Cosmochimica Acta 70:4906-4920. DOI: 10.1016/j.gca.2006.07.019.

222 Chen T, Yu K, Li S, Chen T, Shi Q. 2011. Anomalous Ba/Ca signals associated with low temperature 223 stresses in porites corals from Daya Bay, northern South China Sea. Journal of Environmental Sciences 23:1452-1459. DOI: 10.1016/S1001-0742(10)60606-7.

225

226

227

228

229

230

231

232

233

234

235

236

237

238

239

240

Cho S-M, Jeong W-G. 2011. Prismatic shell repairs by hemoctyes in the extrapallial fluid of the Pacific Oyster, Crassostrea gigas. The Korean Journal of Malacology 27:223-228. DOI: 10.9710/kjm.2011.27.3.223

Cummings KS, Graf DL. 2015. Class Bivalvia. In: Thorp and Covich's Freshwater Invertebrates. Elsevier, 423-506. DOI: 10.1016/B978-0-12-385026-3.00019-X.

Dauphin Y, Denis A. 2000. Structure and composition of the aragonitic crossed lamellar layers in six species of Bivalvia and Gastropoda. Comparative Biochemistry and Physiology Part A: Molecular \& Integrative Physiology 126:367-377. DOI: 10.1016/S1095-6433(00)00213-0.

Gaetani GA, Cohen AL. 2006. Element partitioning during precipitation of aragonite from seawater: a framework for understanding paleoproxies. Geochimica et Cosmochimica Acta 70:4617-4634. DOI: 10.1016/j.gca.2006.07.008.

Heinemann F, Launspach M, Gries K, Fritz M. 2011. Gastropod nacre: structure, properties and growth — Biological, chemical and physical basics. Biophysical Chemistry 153:126-153. DOI: 10.1016/j.bpc.2010.11.003.

Jáuregui-Zúñiga D, Reyes-Grajeda J, Sepúlveda-Sánchez J, Whitaker JohnR, Moreno A. 2003. Crystallochemical characterization of calcium oxalate crystals isolated from seed coats of 
241

242

243 Kennedy WJ, Taylor JD, Hall A. 1969. Environmental and biological controls on bivalve shell

244

245

246

247

248

249

250

251

252

253

254

255

256

257

258

259

260

261

262

263

264

Phaseolus vulgaris and leaves of Vitis vinifera. Journal of Plant Physiology 160:239-245. DOI: 10.1078/0176-1617-00947. mineralogy. Biological Reviews 44:499-530. DOI: 10.1111/j.1469-185X.1969.tb00610.x.

Ky C-L, Lo C, Planes S. 2017. Mono- and polychromatic inner shell phenotype diversity in Pinctada margaritifera donor pearl oysters and its relation with cultured pearl colour. Aquaculture 468:199-205. DOI: 10.1016/j.aquaculture.2016.10.017.

Li X, Chang W-C, Chao YJ, Wang R, Chang M. 2004. Nanoscale structural and mechanical characterization of a natural nanocomposite material: the shell of red abalone. Nano Letters 4:613-617. DOI: 10.1021/n1049962k.

Liu X, Li J. 2015. Formation of the prismatic layer in the freshwater bivalve Hyriopsis cumingii: the feedback of crystal growth on organic matrix. Acta Zoologica 96:30-36. DOI: 10.1111/azo.12048.

Marin F. 2012. The formation and mineralization of mollusk shell. Frontiers in Bioscience S4:10991125. DOI: $10.2741 / \mathrm{s} 321$.

Marsh ME, Sass RL. 1983. Calcium-binding phosphoprotein particles in the extrapallial fluid and innermost shell lamella of clams. Journal of Experimental Zoology 226:193-203. DOI: 10.1002/jez.1402260204.

Monarumit N, Noirawee N, Phlayrahan A, Promdee K, Won-in K, Satitkune S. 2015. Identification of high-luster and lusterless freshwater-cultured pearls by X-ray absorption spectroscopy. Journal of Applied Spectroscopy 82:677-680. DOI: 10.1007/s10812-015-0163-3.

Morris JP, Wang Y, Backeljau T, Chapelle G. 2016. Biomimetic and bio-inspired uses of mollusc shells. Marine Genomics 27:85-90. DOI: 10.1016/j.margen.2016.04.001.

Muhammad G, Atsumi T, Sunardi, Komaru A. 2017. Nacre growth and thickness of Akoya pearls from Japanese and Hybrid Pinctada fucata in response to the aquaculture temperature condition in Ago Bay, Japan. Aquaculture 477:35-42. DOI: 10.1016/j.aquaculture.2017.04.032.

Peer) reviewing PDF | (2021:01:57287:1:0:NEW 2 May 2021) 
267 Nakamura Filho A, Almeida AC de, Riera HE, Araújo JLF de, Gouveia VJP, Carvalho MD de, Cardoso 268 AV. 2014. Polymorphism of $\mathrm{CaCO}_{3}$ and microstructure of the shell of a Brazilian invasive 269 270 mollusc (Limnoperna fortunei). Materials Research 17:15-22. DOI: 10.1590/S151614392014005000044.

271 Oaki Y, Imai H. 2005. The hierarchical architecture of nacre and its mimetic material. Angewandte $272 \quad$ Chemie International Edition 44:6571-6575. DOI: 10.1002/anie.200500338.

273 Okumura T, Suzuki M, Nagasawa H, Kogure T. 2012. Microstructural variation of biogenic calcite with 274 intracrystalline organic macromolecules. Crystal Growth \& Design 12:224-230. DOI: $275 \quad 10.1021 / \operatorname{cg} 200947 \mathrm{c}$.

276 de Paula SM, Silveira M. 2009. Studies on molluscan shells: contributions from microscopic and 277 analytical methods. Micron 40:669-690. DOI: 10.1016/j.micron.2009.05.006.

278

279

280

281

282

283

284

285

286

287

288

289

290

Ren F, Wan X, Ma Z, Su J. 2009. Study on microstructure and thermodynamics of nacre in mussel shell. Materials Chemistry and Physics 114:367-370. DOI: 10.1016/j.matchemphys.2008.09.036.

Romana L, Thomas P, Bilas P, Mansot JL, Merrifiels M, Bercion Y, Aranda DA. 2013. Use of nanoindentation technique for a better understanding of the fracture toughness of Strombus gigas conch shell. Materials Characterization 76:55-68. DOI: 10.1016/j.matchar.2012.11.010.

Rousseau M, Meibom A, Gèze M, Bourrat X, Angellier M, Lopez E. 2009. Dynamics of sheet nacre formation in bivalves. Journal of Structural Biology 165:190-195. DOI: 10.1016/j.jsb.2008.11.011.

Saruwatari K, Matsui T, Mukai H, Nagasawa H, Kogure T. 2009. Nucleation and growth of aragonite crystals at the growth front of nacres in pearl oyster, Pinctada fucata. Biomaterials 30:30283034. DOI: 10.1016/j.biomaterials.2009.03.011.

Saunders WB, Landman NH (eds.). 2010. Nautilus: the biology and paleobiology of a living fossil, Reprint with additions. Dordrecht: Springer Netherlands. DOI: 10.1007/978-90-481-3299-7. 
291 Shi L, Wang Y, Liu X, Mao J. 2018. Component analysis and identification of Black Tahitian cultured 292 pearls from the oyster Pinctada margaritifera using Spectroscopic Techniques. Journal of 293 Applied Spectroscopy 85:98-102. DOI: 10.1007/s10812-018-0618-4.

294 Shtukenberg AG, Ward MD, Kahr B. 2017. Crystal growth with macromolecular additives. Chemical 295 Reviews 117:14042-14090. DOI: 10.1021/acs.chemrev.7b00285.

296 Suzuki M, Nagasawa H. 2013. Mollusk shell structures and their formation mechanism. Canadian 297 Journal of Zoology 91:349-366. DOI: 10.1139/cjz-2012-0333.

298 Tang Z, Kotov NA, Magonov S, Ozturk B. 2003. Nanostructured artificial nacre. Nature Materials 299 2:413-418. DOI: 10.1038/nmat906.

300 Taylor J, Strack E. 2008. Pearl oroduction. In: The Pearl Oyster. Elsevier, 273-302. DOI: 10.1016/B978301 $0-444-52976-3.00008-5$.

302 303 304 305 306 307 308 309 310 311

Towe KM, Hamilton GH. 1967. Ultrastructure and inferred calcification of the mature and developing nacre in bivalve mollusks. Calcified Tissue Research 1:306-318. DOI: 10.1007/BF02008102.

Veis A, Dorvee JR. 2013. Biomineralization mechanisms: a new paradigm for crystal nucleation in organic matricies. Calcified tissue international 93:307-315. DOI: 10.1007/s00223-012-9678-2.

WADA K. 1972. Nucleation and growth of aragonite crystals in the nacre of bivalve molluscs. Biomineralization 6:141-159.

Wada KT, Tëmkin I. 2008. Chapter 2 - Taxonomy and Phylogeny. In: Southgate PC, Lucas JS eds. The Pearl Oyster. London: Elsevier, 37-75. DOI: 10.1016/B978-0-444-52976-3.00002-4.

Wang RZ, Suo Z, Evans AG, Yao N, Aksay IA. 2001. Deformation mechanisms in nacre. Journal of Materials Research 16:2485-2493. DOI: 10.1557/JMR.2001.0340.

Wang S-N, Yan X-H, Wang R, Yu D-H, Wang X-X. 2013. A microstructural study of individual nacre tablet of Pinctada maxima. Journal of Structural Biology 183:404-411. DOI: 10.1016/j.jsb.2013.07.013.

Wegst UGK, Bai H, Saiz E, Tomsia AP, Ritchie RO. 2015. Bioinspired structural materials. Nature Materials 14:23-36. DOI: 10.1038/nmat4089. 
317 Weiner S, Traub W. 1980. X-ray diffraction study of the insoluble organic matrix of mollusk shells. FEBS 318 Letters 111:311-316. DOI: 10.1016/0014-5793(80)80817-9.

$319 \mathrm{Xu}$ J, Zhang G. 2015. Unique morphology and gradient arrangement of nacre's platelets in green mussel 320 shells. Materials Science and Engineering: C 52:186-193. DOI: 10.1016/j.msec.2015.03.051.

321 Zhang G, Li X. 2012. Uncovering aragonite nanoparticle self-assembly in nacre-A natural armor.

322 Crystal Growth \& Design 12:4306-4310. DOI: 10.1021/cg3010344.

323 Zhang R, Xie L, Yan Z. 2019. Biomineralization mechanism of the pearl oyster, Pinctada fucata.

324 Singapore: Springer Singapore. DOI: 10.1007/978-981-13-1459-9.

325 Zhang N, Yang S, Xiong L, Hong Y, Chen Y. 2016. Nanoscale toughening mechanism of nacre tablet. 326 Journal of the Mechanical Behavior of Biomedical Materials 53:200-209. DOI:

$327 \quad$ 10.1016/j.jmbbm.2015.08.020.

328

329 


\section{Figure 1}

Scanning electron microscopy (SEM) image of the cross-section of Pteria colymbus (Mollusca, Bivalvia) shell.

General view of pearl oyster Pteria colymbus (Mollusca, Bivalvia) shell showing the prismatic layer $(\mathrm{PL})$ at the lower end, followed by the interface zone $(\mathrm{BL})$ and the nacreous layer $(\mathrm{NL})$ at the top. Middle zone of the nacreous layer (IL).

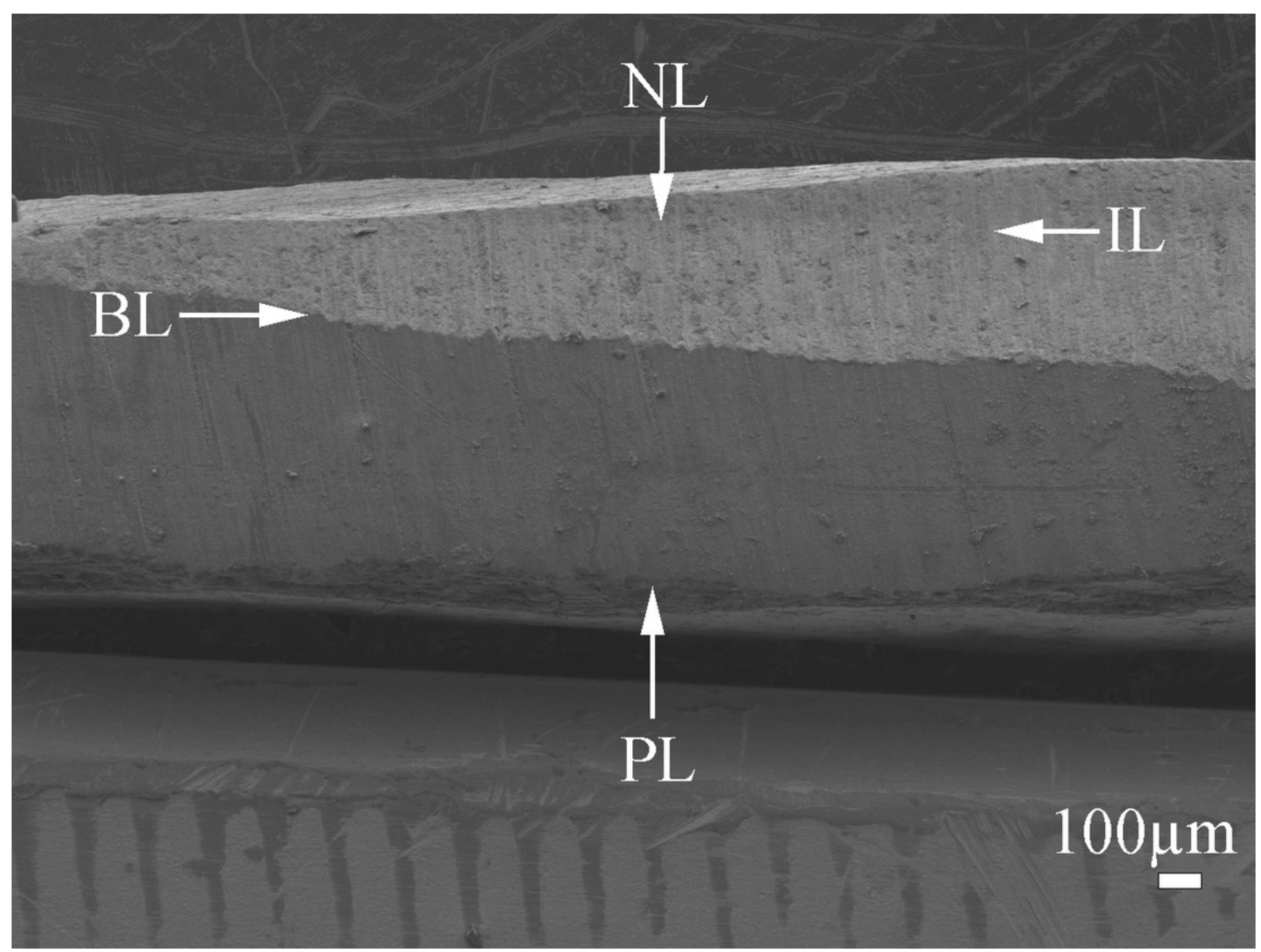




\section{Figure 2}

Scanning electron microscopy (SEM) view of the inner surface of the Pteria colymbus (Mollusca, Bivalvia) shell.

Microstructure of the nacreous tablets in the inner surface of the Pteria colymbus shell. The sample did not receive any polishing and etching treatment. (a) detail of the inner surface of the shell showing recently formed nacre tablets and traces of the hydrogel (arrow) responsible for the formation of the nacre tablets. (b) Detail showing the first stages of nacre crystal formation. Crystal enveloped by organic matrix $(\star)$. Crystal in an advanced stage of formation merging with neighboring crystals (粦). (c) Section showing the two different layers of nacre growth merging through a hexagonal-shaped tablet (arrow). (d) Detail of the last layer of nacre showing the different geometries of the nacre tablets. tablet with the minimum number of sides for this species with only $5 \mu \mathrm{m}$ in length $(\star)$. Tablet fused with others with no apparent pattern, which is $40 \mu \mathrm{m}$ long (鿇). 

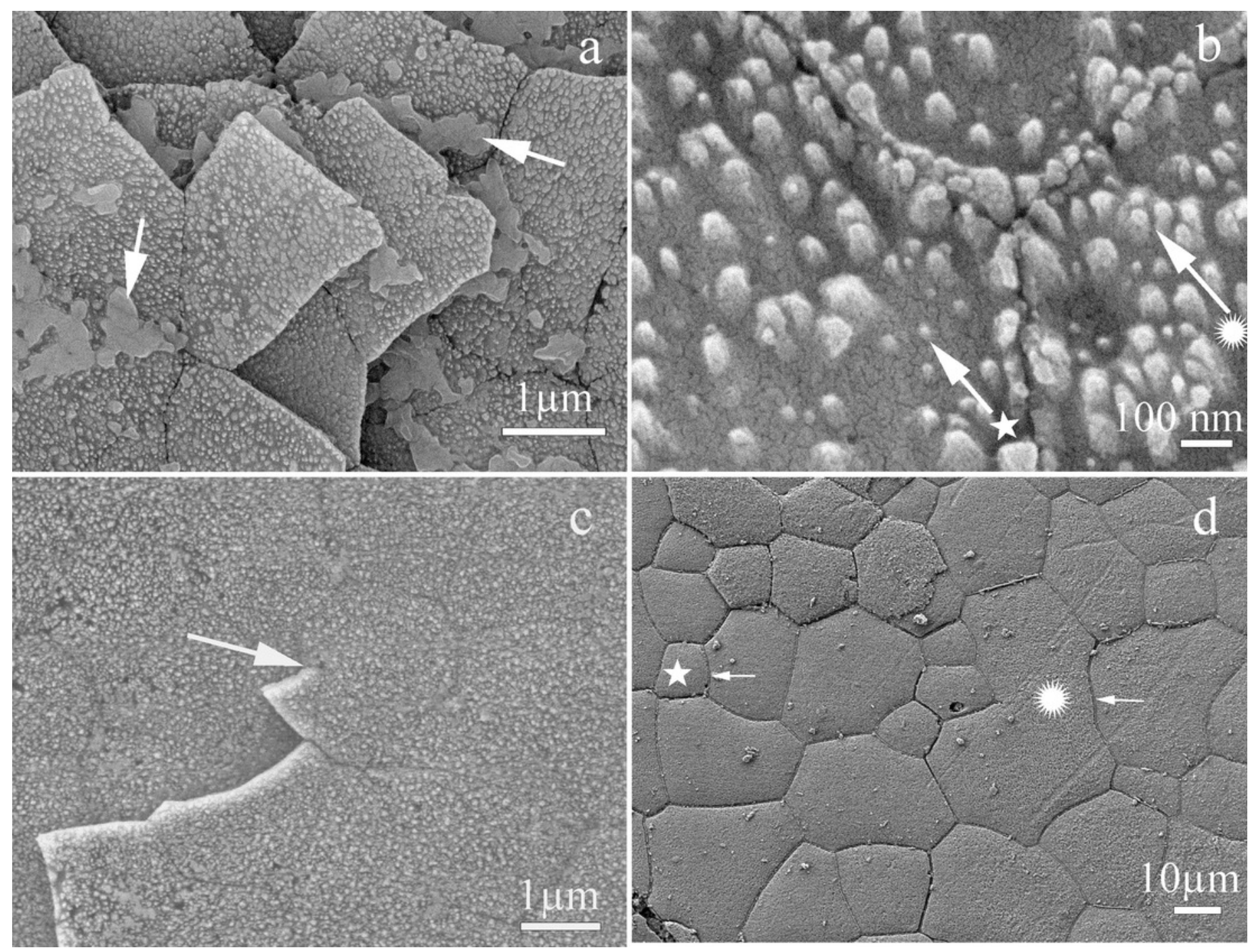


\section{Figure 3}

Scanning electron microscope view of the transverse section of Pteria colymbus (Mollusca, Bivalvia) shell.

Microstructure of the first and middle nacre layers in the shell of Pteria colymbus. (a) Interface zone of the prismatic and nacreous layers. The first layer of nacre crystals has a growth direction perpendicular to the surface (Arrow). The crystals have a greater length compared to the subsequent layers. The next three nacre layers (NL) have better organization and uniform size. (b) Detail of the nacre crystals (NL) in the first stage of growth. The presence of organic hydrogel $(\mathrm{H})$ is observed, which is covering the prismatic layer (PL). (c) Middle zone of the nacre layer. All nacreous layers contain tablets composed of fused individual crystals. The typical brick and mortar formation, typical of bivalve mollusks (represented by white lines) is observed. The average thickness of the tablets was $385 \mathrm{~nm}$ $(S D=0.069)$. (d) Detail of the nacreous layers in the middle zone. The uniform shapes of the tablets are observed, the crystals that make up the tablets show an early stage of growth $(\star)$. Crystals merging from the center in the previous layer (荭). the crystals have a mean width of $41 \mathrm{~nm}(\mathrm{SD}=9.43)$. 


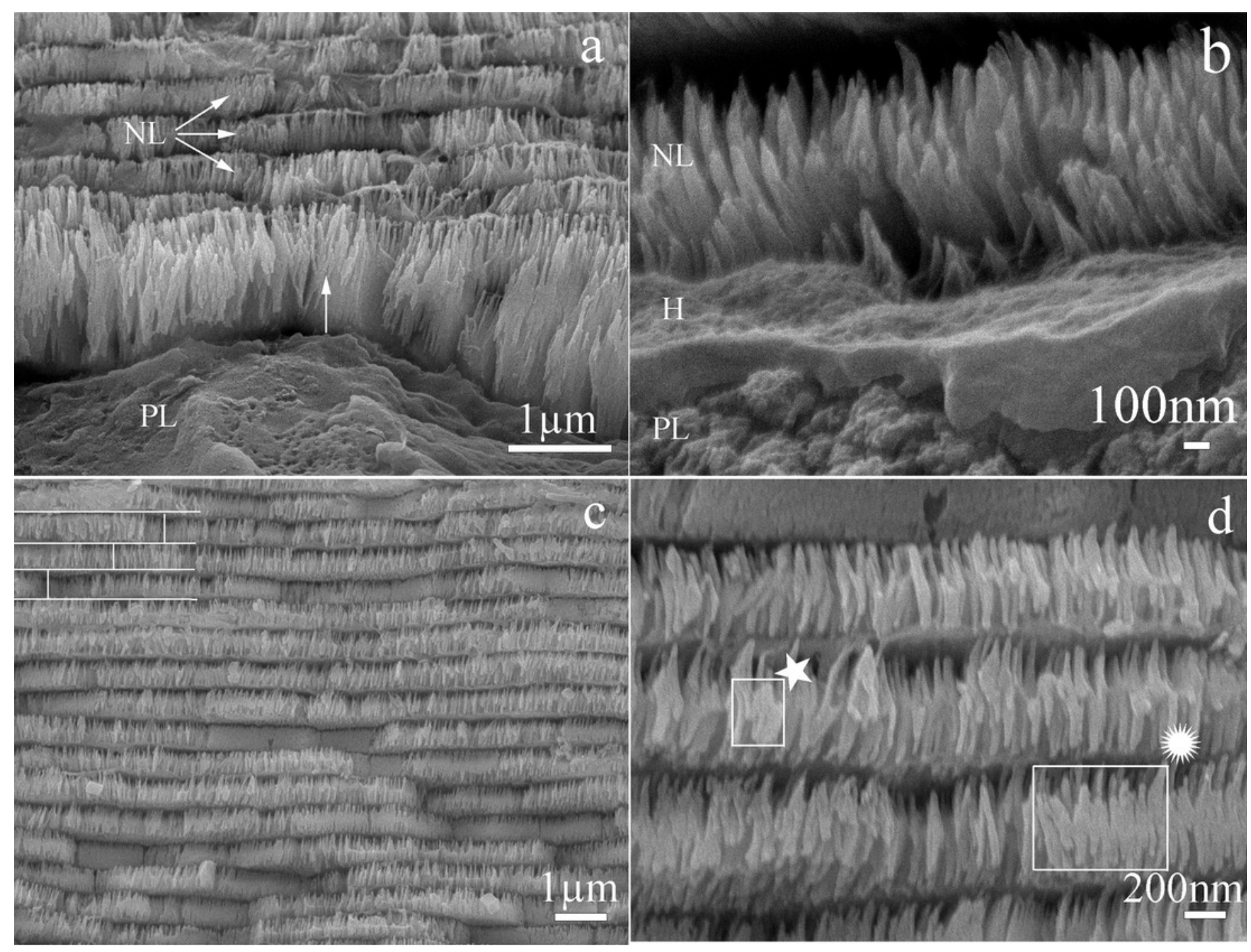


Figure 4

X-ray diffraction pattern (XRD) of Pteria colymbus (Mollusca, Bivalvia) nacre sample.

The stronger diffraction peak of aragonite in nacreous layer of Pteria colymbus is scanning angle $2 \theta=31.05^{\circ}$. Red bars represent the Aragonite pattern from PDF 041-1475. (For interpretation of the references to color in this figure legend, the reader is referred to the web version of this article).

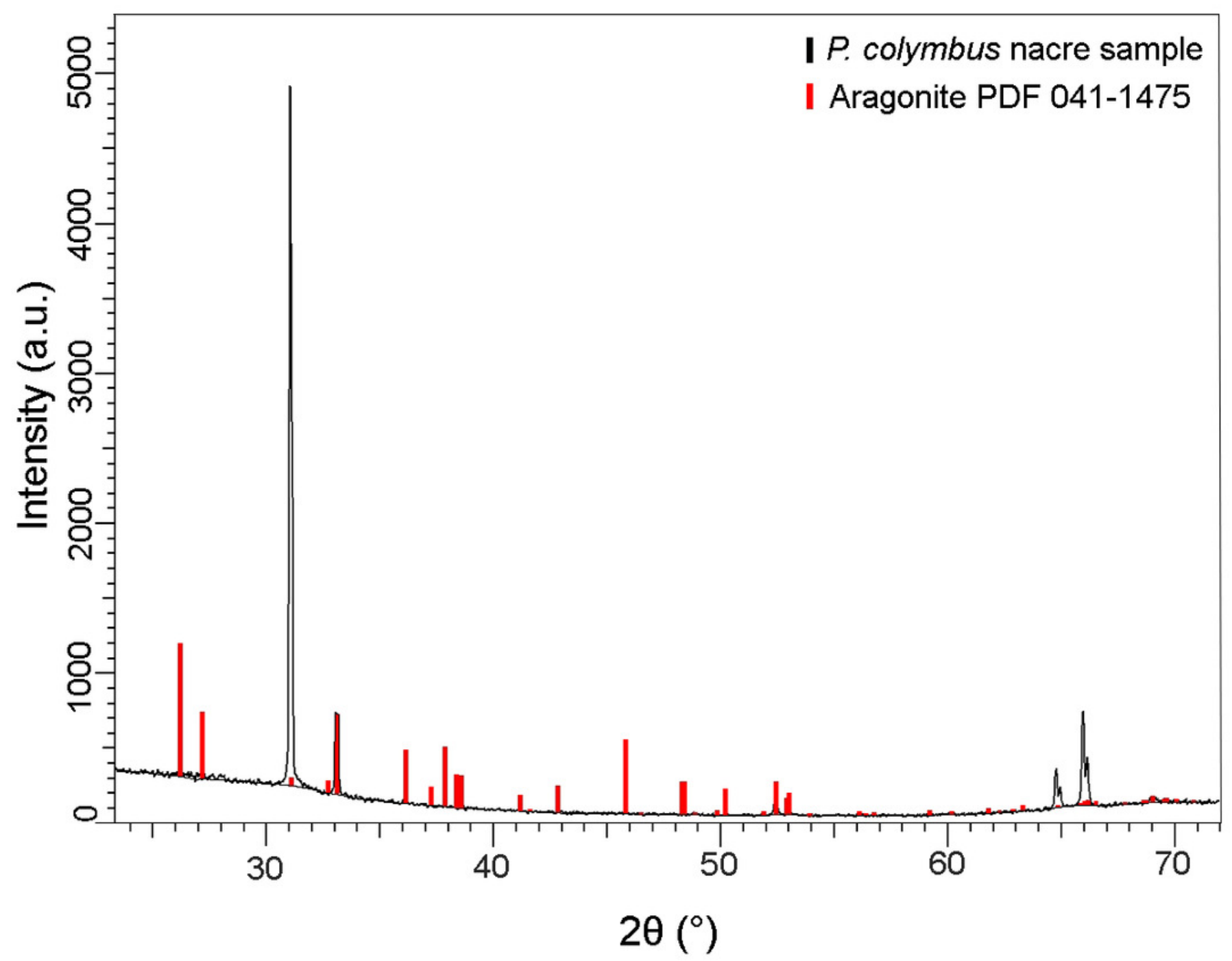


Figure 5

Fourier transform infrared spectrometry (FTIR) spectrum of Pteria colymbus (Mollusca, Bivalvia) nacre powder.

The nacre powder sample of Pteria colymbus displays a characteristic symmetric carbonate stretching vibration (v1) at $1082.72 \mathrm{~cm}^{-1}$ and a carbonate out-of-plane bending vibration (v2) at $856.80 \mathrm{~cm}^{-1}$. The $\mathrm{v} 4$ band at $699.81-712.52 \mathrm{~cm}^{-1}$ corresponds to the planar flexion mode of carbonate vibration.

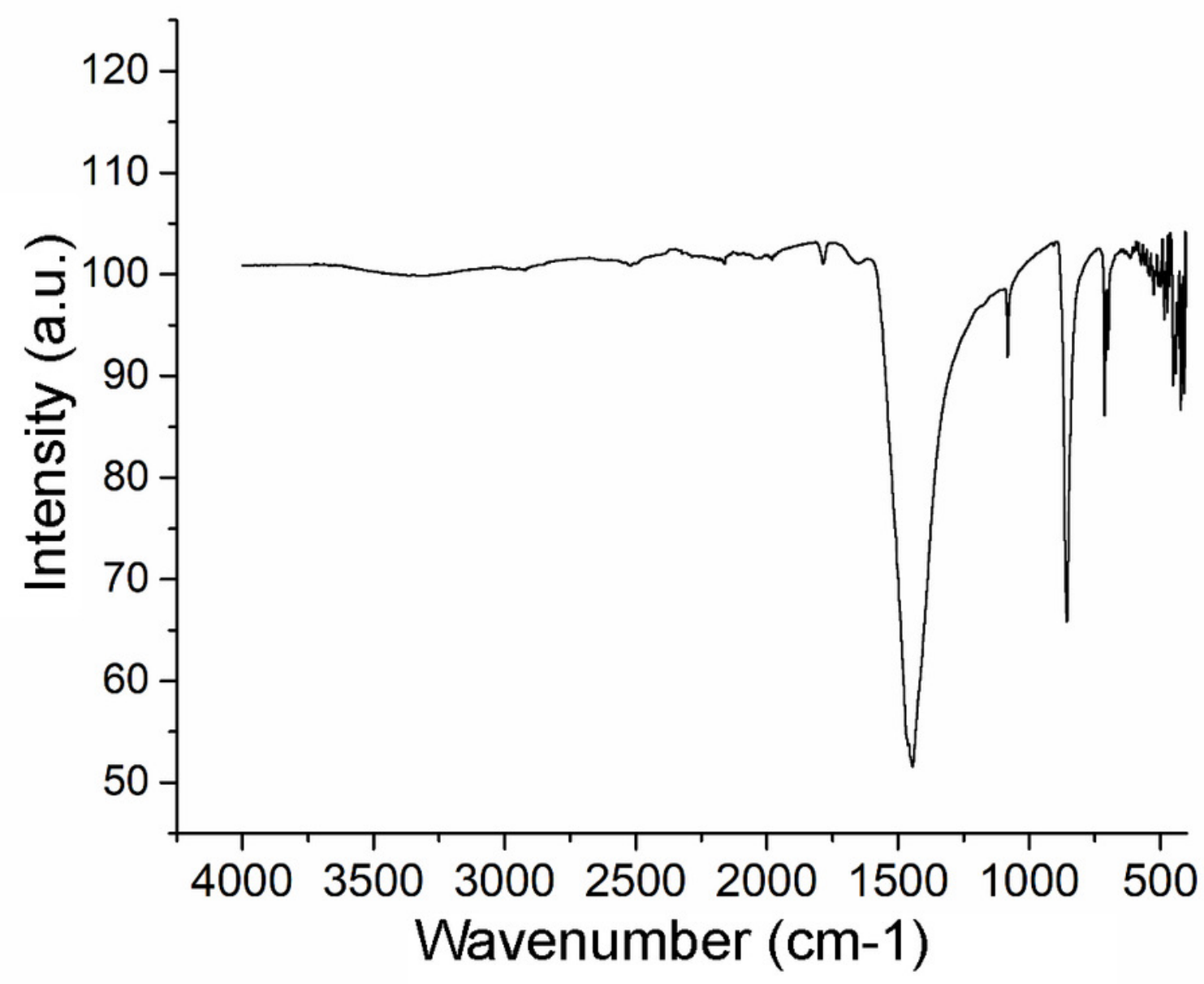




\section{Figure 6}

Raman spectra of the Pteria colymbus (Mollusca, Bivalvia) nacre layer sample.

The nacreous layer of Pteria colymbus shows an intense band at near $1085 \mathrm{~cm}^{-1}$ that corresponds to the symmetrical stretching mode of the carbonate ion. Low- to mediumintensity bands in the $100-300 \mathrm{~cm}^{-1}$ region were due to the translational and rotational modes of lattice vibration. The carbonate ion plane bending mode occurred as a band between 701 and $705 \mathrm{~cm}^{-1}$.

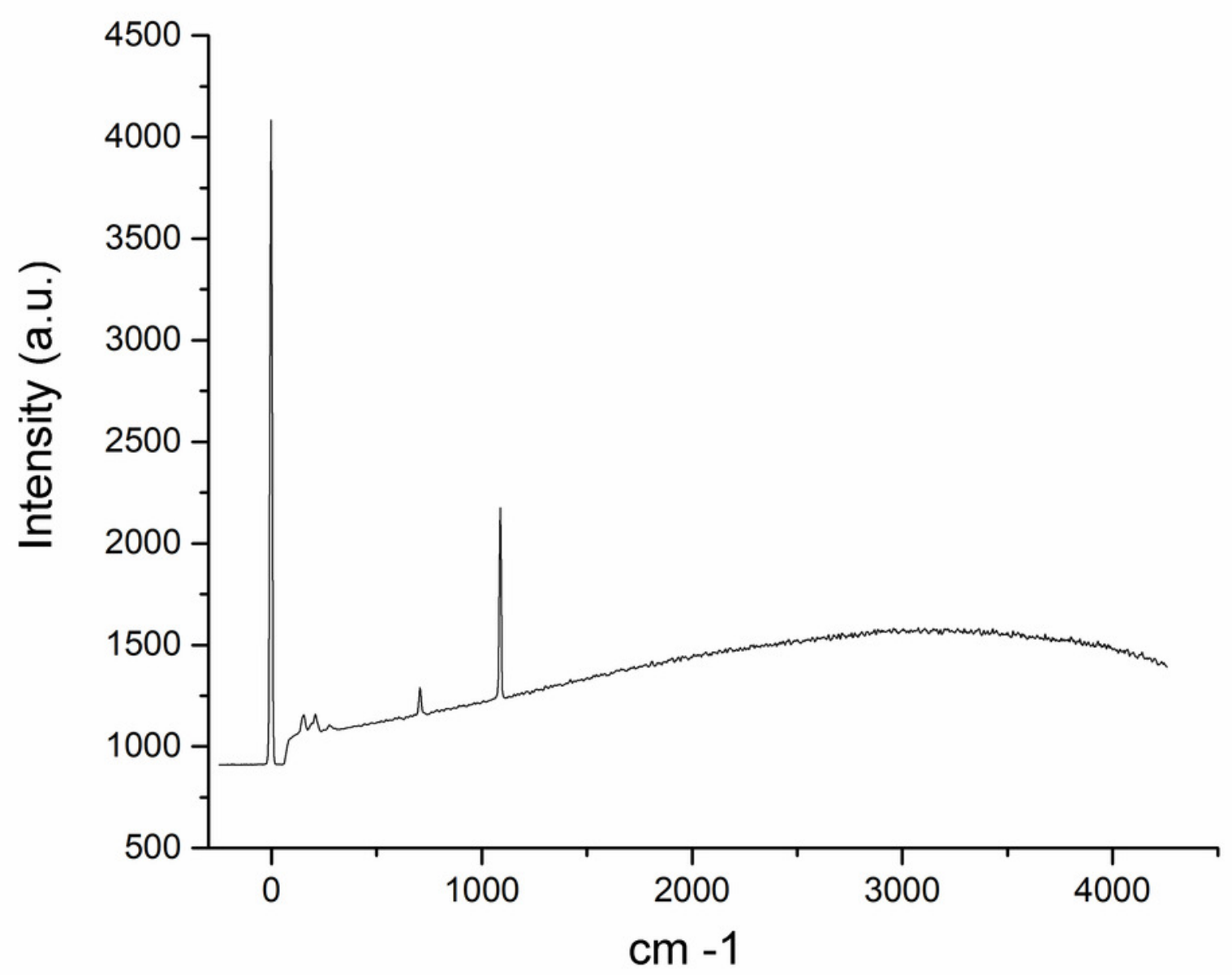

